\title{
Between love and boycott: a story of dual origin brands
}

Between love

\section{Entre el amor y el boicot: una historia sobre marcas con origen dual}

\author{
Dalia Abdelwahab, Nadia Jiménez, Sonia San-Martín and \\ Jana Prodanova \\ Faculty of Economic and Business Sciences, University of Burgos, Burgos, Spain
}

\begin{abstract}
Purpose - This research aims to address ethnocentric consumers' willingness to boycott dual origin brands, in the particular case of national brands linked to a very specific regional origin, through analysing the paradox of (unfavourable) regional ethnocentrism versus (favourable) consumer-brand relationship (i.e. brand identification, trust and love) on consumers' decision to buy or boycott those brands in that circumstances. Building on social identity and cognitive dissonance theories, this study aims to examine the Spanish consumer relationship with national brands originated in Catalonia considering the current conflicting circumstances in the region.

Design/methodology/approach - The authors collected data by means of personal questionnaires, distributed among 277 Spanish consumers of Catalan brands of Cava. The data is analysed by using structural equation modelling and linear structural relations.

Findings - After controlling for brand familiarity, the results of this study reveal that ethnocentrism negatively distorts consumers' confidence in dual origin brands and highlight the role of identification and trust as brand love antecedents. It also reveals that ethnocentrism has a more profound impact on boycotting decision than brand love.

Originality/value - This study is one of the few to capture the puzzlement created by the paradoxical nature of the brand's duality of origin. Furthermore, it contributes to the marketing literature by examining the impact of ethnocentrism on two relationship variables (i.e. identification and trust) and exploring their joint impact on consumers' decision to buy or boycott. The findings of this study can be helpful for companies facing boycotting behaviour triggered by ethnocentric consumer reaction towards dual origin brands.
\end{abstract}

Keywords Brand love, Brand relationship, Cava, Dual origin brand, Regional ethnocentrism, Willingness to boycott

Paper type Research paper

(c) Dalia Abdelwahab, Nadia Jiménez, Sonia San-Martín and Jana Prodanova. Published in Spanish Journal of Marketing - ESIC. Published by Emerald Publishing Limited. This article is published under the Creative Commons Attribution (CC BY 4.0) licence. Anyone may reproduce, distribute, translate and create derivative works of this article (for both commercial and non-commercial purposes), subject to full attribution to the original publication and authors. The full terms of this licence maybe seen at http:// creativecommons.org/licences/by/4.0/legalcode

The authors would like to thank the Junta de Castilla y León for financing and supporting this research through scholarship of pre-doctoral recruitment (Order EDU/556/2019).

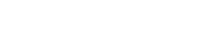


Diseño/método - Los datos se recogieron mediante cuestionarios personales, distribuidos entre 277 consumidores españoles de marcas catalanas de Cava. Los datos se analizaron utilizando modelación de ecuaciones estructurales y relaciones estructurales lineales.

Hallazgos - Después de controlar la familiaridad con la marca, nuestros resultados revelan que el etnocentrismo distorsiona negativamente la confianza de los consumidores en las marcas de origen dual y destaca el papel de la identificación y la confianza como antecedentes del amor por la marca. También revela que el etnocentrismo tiene un impacto más profundo en la decisión de boicotear que el amor por la marca.

Originalidad/valor - Este estudio es uno de los pocos que captura la confusión creada por la naturaleza paradójica de la dualidad del origen de la marca. Además, contribuye a la literatura de marketing al examinar el impacto del etnocentrismo en dos variables relacionales (la identificación y la confianza) y explorar su impacto conjunto en la decisión de los consumidores de comprar o boicotear. Nuestros hallazgos pueden ser útiles para las empresas que se enfrentan al comportamiento de boicot provocado por la reacción etnocéntrica de los consumidores hacia las marcas de origen dual.

Palabras clave Etnocentrismo regional, Relación de marca, Marca de origen dual, Disponibilidad para boicotear, Cava, Amor por la marca

Tipo de artículo Trabajo de investigación

\section{Introduction}

In sociology, ethnocentric variations and regionalism are a couple of the major reasons for in-group/out-group preference or bias within one nation. Regions are considered to be more homogenous than countries, but at the same time, these could be highly heterogeneous from one another in some countries.

Various research studies began to direct their investigations towards "place" rather than "country" of origin, focussing the attention on the diversity that exists within a nation, as a major source of behavioural variations (Fernández-Ferrín and Bande-Vilela, 2013). These kinds of diversities can stimulate stronger in-group regional attachments, manifested in the form of regional ethnocentrism. Consumers can, therefore, develop a highly biased tendency towards regional purchase over national or foreign (García-Gallego and Chamorro-Mera, 2017). However, literature is not so clear about what happens when the regional identity of a brand becomes unfavourable in the eyes of national consumers.

In today's local markets, tones of hybrid brands - products with components from different origins - compete against regionally produced ones for a bigger portion of the market (Cheah et al., 2016). To outshine their rivals, companies use various differentiation strategies that distinguish their products' uniqueness from competitors. One differentiation technique used by both companies and consumers is the geographical origin clues (Fernández-Ferrín and Bande-Vilela, 2013; Teuber, 2010), where companies use it as a crucial indicator for their brands' superiority. Meanwhile, consumers use it -especially in complex markets - to form a comprehensive purchasing opinion about a brand and to facilitate decision-making process (Charton-Vachet and Lombart, 2018; Teuber, 2010).

Studying consumer perception towards brands originated from different parts of the world has been a topic of great interest to marketing researchers. Plenty of cross-national 
studies discuss the influence of the product origin on consumers' decision to buy or boycott certain brands. Consumer ethnocentrism (Fernández-Ferrín and Bande-Vilela, 2015; Truong, 2018) and boycotting behaviour (Farah and Newman, 2010; Maher and Mady, 2010; Riefler and Diamantopoulos, 2007) are some of the discussed issues in the marketing literature that pay keen attention to the effect of the products and brands' place of origin.

Surprisingly enough, abundant of the literature limit the categorisation of their chosen products to one single origin trait, either being local (Lesáková, 2016), regional (Ahmed et al., 2018; Lee et al., 2016) or foreign product (Lee and Mazodier, 2015; Truong, 2018). However, many products combine distinctive multiple origin features (Fernández-Ferrín et al., 2018) that should be taken into account when analysing consumer purchasing behaviour. In this study, we focus our attention on brands with traits of being "national" brand with a high association to a specific "regional" origin at the same time. We will refer to such brands as "dual origin brands".

The objectives of this research can be illustrated as follows. Firstly, we jointly examine the counteractive impact of two broad sets of research topics - ethnocentrism and consumer-brand relationship - that were independently investigated in the past, on consumer's willingness to participate in a boycott act against dual origin brands. Secondly, this research aims to pinpoint the negative influence created by ethnocentric consumer rejection on two vitally important brand relationship variables - identification and trust - for brands with a duality of origin. Thirdly, it also captures the paradoxical effects on boycott when the brand's duality of origin is analysed under specific circumstances (i.e. a particular case affected by political conflict). Specifically, for brands perceived simultaneously as both national and regional, where these specific brands might suffer during an intragroup negative ad hoc event, because of the (national) brands' high association to a region with current conflicting circumstances, which implies a discordant perception - unfavourable and favourable - about a brand.

To summarise, given the focal role of the specific (origin) traits associated with the brands in question, this study examines brands described as being national brands originated from a conflicting regional origin simultaneously, which creates a discordant perception - favourable versus unfavourable - towards the brands. Our model presented in Figure 1 proposes a negative influence of regional ethnocentrism on the consumer's relationship with brands that are national but originated from an unfavourable region, such as Catalonia; examines the strength of positive relationship between three brand relationship variables (i.e. identification, trust and love) for such specific brands (i.e. with complex nature); and investigates the direct forces of ethnocentrism and brand love, in relation to consumer's willingness to boycott national brands linked to the Catalan region.

\section{Theoretical background and proposed hypotheses}

Our research has been thoroughly founded on two widely used theories in the literature of ethnocentrism, brand relationships and boycotting context, which are the social identity theory (Lee et al., 2016; Oberecker and Diamantopoulos, 2011; So et al., 2013) and the cognitive dissonance theory (Cheah et al., 2016; Lee et al., 2016; So et al., 2013). These theories

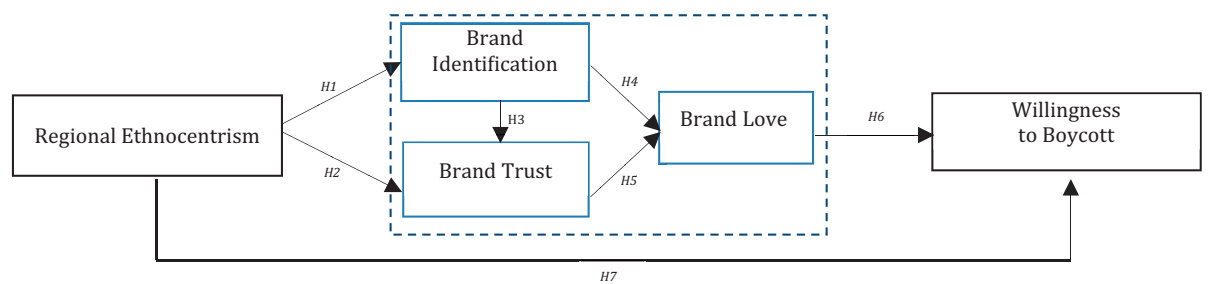

Between love and boycott 
assist us in explaining the relationship between our model variables and capture the opposite impacts of brand's duality of origin on the consumer decision-making process. But first, we devote the next epigraph to detail what are dual origin brands.

\subsection{Dual origin brands}

A dual origin brand is understood here, as a brand that has (simultaneously) both a regional and a national origin. Both extrinsic attributes (regional origin and national origin) have demonstrated an essential role in consumer perception and behaviour (Chamorro et al., 2015). Furthermore, prior studies have proven that consumers indeed distinguish and considered in their evaluation of agri-food products both origins (Orth and Krška, 2001). National brands are goods produced inside the geographical boundaries of a national state or country and are widely available to local consumers throughout extensive channels across the country (Sirvanl, 2011). In other words, national brands are regional or multiregional brands (García-Gallego and Chamorro-Mera, 2017) that have a countrywide presence, and their availability is not limited to a specific regional or geographic location within a country.

In the case of regional brands, the territorial origin of the product, as well as the combination of different traditional factors (human, natural and productive), is of great importance to differentiate regional products and give them organoleptic properties and qualities that are difficult to imitate (Fernández-Ferrín et al., 2018). Beyond this explanation, we can also describe brands that maintain a strong regional voice, through distinct regional features that are hard to be mimicked elsewhere, as regional brands (Fernández-Ferrín et al., 2018).

As previously mentioned, brands could be described through different origin clues and associations (Fernández-Ferrín et al., 2018). In fact, not only consumers can evaluate brands that are entirely local or entirely foreign (Lopez-Lomelí et al., 2019) but also they can recognise and evaluate brands that have varied origin clues, which many of the brands they buy possess (Cheah, 2010; Kipnis et al., 2012; Samiee et al., 2005). In other words, research acknowledges the capability of the consumer to (simultaneously) associate brands with multiple origin clues and identities (Samiee et al., 2005). Actually, previous research indicates that consumers (especially ethnocentric ones) perceive brands that are entirely domestic, different from those brands that integrate both local (in-group) and foreign (outgroup) origin perspectives (Cheah, 2010). As a matter of fact, brands that encompass both domestic and foreign identities can easily confuse the consumers and create a dissonance of conflicting views about the brand's different origins, which could sometimes be hard for the consumers to reconcile (Cheah, 2010; Kipnis et al., 2012).

Having said that, many of the brands that possess multiple origin associations seek to embrace and place importance on the origin characteristic or identity (either the in-group or out-group character) that can bring them closer to their target market (Cheah, 2010).

On a regional setting, Charton-Vachet and Lombart (2018) suggest that nowadays brands can choose between adopting a regional positioning and offer typical products from the region or adopt a national positioning and offer a non-emblematic product of any region. Even in the second choice, if consumers build strong relationships with brands, they are able to distinguish those companies as based and originated in a particular region.

This study tries to delve into what happens to brands with a duality of origin, when there is a dissonance between the regional and national brand positioning, emerged from a particular (and/or circumstantial) political conflict between the two origins. More specifically, we analyse (Cava) brands with dual origin nature, combining features of being Spanish brands with strong regional (Catalan) identity simultaneously. In the particular 
case that the region of Catalonia could be currently perceived as unfavourable origin, triggered by contextual political and cultural conflicts between the region and the rest of the Spanish nation (Oskam, 2014), which might cause consumers' confusion of how to perceive the brand and whether to buy or boycott such brand, founded on the favourability of one origin (i.e. a well-known in-group Spanish brand) or the unfavourability of the other (i.e. a strongly connected brand to a region with conflicting circumstances).

\subsection{Consumer ethnocentrism}

The concept of ethnocentrism was initially introduced in sociology literature by Sumner (1906, p.13). He describes ethnocentrism as "the view of things in which one's own group is the centre of everything, and all others are scaled and rated with reference to it". Ethnocentric individuals believe that their own group is better than others. Furthermore, they welcome cultures similar to their own, while blocking any interaction with individuals of non-similar cultural background (Jacobi, 2018; Siamagka and Balabanis, 2015). Ethnocentrism is described as a self-defence mechanism used by local communities, governments and individuals to protect their in-group economy from the threat of foreign rivalry (Siamagka and Balabanis, 2015).

One of the first studies that adapted ethnocentrism into the marketing literature was Shimp and Sharma's (1987). They describe consumer ethnocentrism as the beliefs associated with the morality of foreign products purchase. Ethnocentric consumers are strongly biased towards locally manufactured products while avoiding, if possible, products originating outside their community. This attitude is driven by the perception that buying foreign-made products is unpatriotic and may damage the domestic economy (Sharma et al., 1994; Shimp and Sharma, 1987).

Since then, and throughout the years, consumer ethnocentrism has been an evolving concept in the context of the marketing literature. It became a central construct in many cross-cultural studies of international marketing (Fernández-Ferrín and Bande-Vilela, 2015; Jiménez and San Martín, 2016; Lee and Mazodier, 2015; Truong, 2018). Numerous studies capture its positive association with local purchasing behaviour (Lesáková, 2016). Others analyse the biased negative attitude against foreign products purchase (Lee and Mazodier, 2015; Truong, 2018).

Another stream of research examines the collective influence of ethnocentrism on domestic versus foreign product purchase (Sharma, 2015; Siamagka and Balabanis, 2015). For instance, Balabanis and Diamantopoulos (2004) argue that ethnocentrism is more capable of explaining domestic products' bias than foreign products' rejection. Furthermore, they acknowledge that ethnocentrism does not have a unified impact across all foreign origins; it depends on the specific place of origin and the product category. Moreover, another study by Oberecker and Diamantopoulos (2011) captures the joint impact of ethnocentrism and country affinity (i.e. favourable consumer feeling towards a particular foreign origin) on consumer willingness to buy products originated from a preferred country. They argue that ethnocentric consumers who favour a certain country can be motivated to act differently with respect to their purchase decision.

Nevertheless, we find that the majority of previous studies limited their investigations on analysing ethnocentrism from the national perspective among countries (Lee and Mazodier, 2015; Truong, 2018), disregarding that this concept can also be applied on more local or regional level within one community or country (Ahmed et al., 2018; Fernández-Ferrín et al., 2017; Fernández-Ferrín et al., 2018). However, some literature highlights ethnocentrism on a regional level (Fernández-Ferrín et al., 2018; García-Gallego and Chamorro-Mera, 2016; García-Gallego and Chamorro-Mera, 2018; García-Gallego et al., 2015). For instance,
Between love and boycott

381 
Fernández-Ferrín and Bande-Vilela (2015) analyse the Spanish regional ethnocentrism, indicating that strongly identified consumers with their regions believe in the superiority of their regional products and consequently favour the purchase of regional over non-regional products.

Despite previous exceptions, the regional context has not been the focus of previous ethnocentrism literature. Some studies highlight its relation with the willingness to buy nonregional products (Ahmed et al., 2018; Lee et al., 2016). Others discuss the influence of being highly regional or national ethnocentric on altering the attitude of the consumer towards out of group products (Ouellet, 2007; Siemieniako et al, 2011).

\subsection{Consumer-brand relationship}

The consumer-brand relationship, as conceptualised here, represents the strength of positive connection created between the consumer and a preferred brand. Consumers who develop a profound relationship with a brand may perceive that brand as a partner or try to humanise it with human features and characteristics (Fournier, 1998). Furthermore, consumers build relationships with brands through different emotional categories, as the intensity of the relationship gets stronger, more profound emotional ties are created in the form of brand trust and/or brand love (Ha and Perks, 2005; Veloutsou and DelgadoBallester, 2018). In this study, we shed light on several central relationship constructs (i.e. brand identification, trust and love), which often appear associated in psychology (Fehr, 1988). We believe that these constructs shall help us to explain the proximity of relationship with brands of dual origin nature.

Consumer perception regarding brand excellence is no longer about the basic characteristics and features of the product; it becomes more deeply founded on the brand's ability to represent various symbolic meanings and benefits to its customers (Tuškej and Podnar, 2018). A brand that can help to articulate its consumer identity (i.e. personal and social identity) is more preferred than other brands that cannot enhance the self-image of the consumer or present him/her elegantly and successfully to others (Stokburger-Sauer et al., 2012). Knowing that we believe that studying brand identification, which is defined as the "customer's psychological state of perceiving, feeling, and valuing his or her belongingness with a brand" (Lam et al., 2012, p.307), is essential to comprehend the relationship that consumer shares with dual origin brands (Rather et al., 2018; Romero and Ruiz-Equihua, 2020).

Previous studies on this topic identified two distinct dimensions of brand identification, which are personal and social brand identification (Carroll and Ahuvia, 2006; Del Río et al., 2001; Sukortprommee, 2013). Indicating that, on the personal level, consumers would strongly identify themselves with brands that are a close match to their actual or ideal self. Meanwhile, on the social level, consumers choose brands that can better position them in the eyes of others and can facilitate their acceptance into the desired group or social class (Del Río et al., 2001; Sukortprommee, 2013).

Another interesting brand relationship construct that we consider in our research is "brand trust", defined as the willingness to count on a certain brand's ability to perform its expected function and stand by its promises (Bhandari and Rodgers, 2018). Consumers are convinced that they are dealing with a respectable brand, whenever trust is the fundamental baseline of their relationship. In other words, brands that take their duties and responsibilities seriously and care about the interest and welfare of their consumers are perceived as more credible and reliable than others that do not follow the same pattern (Bhandari and Rodgers, 2018) and eventually facilitate the development of a successful, long-lasting relationship with the brand. 
However, if the consumer harbours negative feelings towards a brand for any reason (e.g. ethnocentric rejection), this feeling may severely impact the level of trust in that brand (Moon et al., 2017) and can jeopardise the relationship with such brand. Brand trust appears to be closely related to the specific origin of the product (Jiménez and San Martín, 2010). Especially when consumers do not consider the intrinsic features of the product and primarily rely on the extrinsic cues to form an opinion about the brand (e.g. country of origin).

Abundant of previous ethnocentric literature adopted in their research the logic of the social identity theory (Tajfel, 1982), which implies that individuals always search for means to differentiate their national social identity from others, in terms of in-/out-group orientation, where the in-group is always more preferable than other out of the group members (Shimp and Sharma, 1987). In the process of social categorisation, individuals attempt to develop and maintain a positive evaluation of the self and the associated social groups. This can be done by classifying themselves and others into in-/out-group members and engaging in comparisons between groups - my group versus yours - (Verlegh, 2007).

Implementing this logic on the ethnocentric context, individuals who demonstrate high levels of ethnocentrism will exhibit stronger attachments to their in-group culture and local traditions and thus show more bias towards local over foreign brands purchase (Shimp and Sharma, 1987). Meanwhile, on a regional level, an ethnocentric consumer can easily bind with regional brands over non-regional ones, behaving in a distinctive manner to protect regional brands against any outsider competing brands that can jeopardise his/her community welfare (Siamagka and Balabanis, 2015).

We agree with previous research in the use of social identity logic in the ethnocentric context. However, because of the duality of origin of our chosen brands, we believe that the cognitive dissonance theory (Festinger, 1957) will be a more appropriate mean to capture the paradoxical nature of the brand (i.e. national brand originated in unfavourable regional origin). This theory implies that, in any given situation, consumers often try to rationalise their choices by seeking consistency among their thoughts, feelings and actions. If one element of this set contradicts another, an uncomfortable dissonance will be created. To avoid or reduce such situation, consumers often engage in a process of attitudinal change to bring all their beliefs and actions into line with one another (Cheah et al., 2016; Lee et al., 2016; Oberecker and Diamantopoulos, 2011).

In this sense, an ethnocentric consumer will face a dilemma of conflicting thoughts, generated by the brand's duality of origin, where he/she will perceive the brand as a favourable national brand, while acknowledging its associated unfavourable regional origin traits. This situation will create tension and confusion in the mind of the consumer (Cheah et al., 2016), where he/she will be eager to resolve such tension and align all his/her thoughts together. We predict that the consumer will focus his attention on the unfavourable regional dimension of the brand and gradually drift apart from the brand. Keeping in mind that we speculate that the consumer will feel less identified with such brands and eventually reject its representation as a true self or social reflection of oneself (Shu et al., 2013). Also, we expect that the consumer will be less willing to rely on such brands to deliver its expected function, and therefore feel less enthusiastic about putting faith and confidence in such brands (Lee and Mazodier, 2015; Truong, 2018). We argue that this situation will cause a fracture in the consumer relationship with brands of dual origin nature and eventually justify boycotting decision. Therefore, we propose the following hypotheses:

H1. Consumer regional ethnocentrism will negatively influence brand identification in the case of dual origin brands.

H2. Consumer regional ethnocentrism will negatively influence brand trust in the case of dual origin brands. 
The concept of love has been used in social psychology to describe feelings of affection among humans; however, over the years, this concept expanded dramatically to include not only feeling between individuals but also intense feelings manifested towards objects and products (Ahuvia et al., 2009). In marketing, brand love is defined by Carroll and Ahuvia (2006, p. 81) as "the degree of passionate, emotional attachment a satisfied consumer has for a particular trade name". Consumers who experience a deep love feeling towards a brand are convinced that their beloved brand is unique and irreplaceable; they are more motivated to make repeated purchase transactions and are willing to invest more in this particular brand (Albert et al., 2008; Batra et al., 2012; Fournier, 1998).

Several brand relationship studies analyse the influence of consumers' identification with brands in the formulation and development of trust in a particular brand (He et al., 2012; So et al., 2013). We argue that, owing to the national traits of dual origin brands, consumers will display more confidence and reliability in brands that better express their true self and enhance their public image (So et al., 2013). Furthermore, we believe that both brand identification and trust will play an antecedent role in the generation of consumer love. Consumers who are strongly identified with a trustworthy brand and have deep ties of confidence with that brand are more capable of developing an intense feeling of love connection towards that brand (Albert and Merunka, 2013). Therefore, we propose the following hypotheses:

H3. Brand identification will positively influence brand trust in the case of dual origin brands.

H4. Brand identification will positively influence brand love in the case of dual origin brands.

H5. Brand trust will positively influence brand love in the case of dual origin brands.

\subsection{Consumer willingness to boycott}

A boycott is an attempt to protest and express dissatisfaction and disapproval towards an offending party's actions or policies through refraining from making a selected purchase transaction (Ettenson and Gabrielle Klein, 2005). A boycott can also be a demonstration of the consumer's support to a particular moral cause or a desire to make a difference (Farah and Newman, 2010; Hashim and Kasana, 2019; Klein et al., 2004; Maher and Mady, 2010). Throughout the years and with the growing number of international transactions, we witness several companies suffer severely from being boycott targets, for reasons far beyond the company's scope of policies or product features (Farah and Newman, 2010; Klein et al., 2004).

International conflicts with the product's associated country could be one reason for consumer animosity (Jiménez and San Martín, 2008; Klein et al., 1998) and boycotting behaviour (Farah and Newman, 2010; Riefler and Diamantopoulos, 2007). For example, Muslim consumers participated in boycotting attempt against Danish goods following a disrespectful comic mocking prophet Muhammad (Maher and Mady, 2010), and Australian consumers boycotting French products after the nuclear test in the South Pacific (Ettenson and Gabrielle Klein, 2005).

Supported by the social identity theory, boycott and brand love literature, this study predicts a possible connection between two of our antecedents - ethnocentrism and brand love - and the consumer's willingness to boycott (Lee et al., 2017; Sarkar et al., 2012; Suetrong et al., 2018). We independently examine the direct impact of both ethnocentrism and brand love on motivating/or weakening the willingness of consumers to refrain from 
buying dual origin brands. Besides, we consider the indirect impact of ethnocentrism on boycott through a series of relationship variables among which is love for brands with dual origin nature. This is because of the fact that these brands have opposite characteristics that can cause confusion to the consumer (i.e. buy or boycott), being originated from an unfavourable region, generating negative feeling stimulated by consumer ethnocentrism. Versus, being a favourable national brand, promoting a positive feeling of love towards those brands.

By one hand, we argue that highly ethnocentric consumers will feel morally obligated to

Between love and boycott support the local economy and defend regional identity (Fernández-Ferrín et al., 2018) through behaving in a protective manner towards their regional brand, which will motivate them to reject foreign-originated brands and consequently participate in a boycott act against foreign brands (Lee et al., 2017).

By the other hand, the love felt towards a particular brand can motivate consumers to make repeated purchase transactions and maintain a continuous and valued relationship with the brand (Fetscherin et al., 2014; Rodrigues and Rodrigues, 2019). We believe that consumers who develop strong affection towards brands featured as nationally originated brands will be less willing to refrain from buying dual origin brands (Sarkar et al., 2012; Suetrong et al., 2018). This indicates that having a deeply strong attachment and passion towards brands with traits of being nationally originated can definitely affect the decisionmaking process and alter consumer buying behaviour. Thus, we propose the following hypotheses:

H6. Brand love will negatively influence willingness to boycott dual origin brands.

H7. Consumer regional ethnocentrism will positively influence willingness to boycott dual origin brands.

The proposed research model and related hypotheses are presented in Figure 1.

\subsection{Mediation effect of consumer-brand relationship links}

Beyond the direct relations, the current study also pays attention to the mediating mechanism within the study framework, to better explain the model relationships from a broader perspective. In particular, we speculate that ethnocentrism will influence the consumer willingness to boycott not only directly but also indirectly through a series of consumer-brand relationship links among which is love for brands with dual origin nature. Prior studies considered the mediating role of several brand relationship variables in the context of the place of origin literature. For instance, the studies of Guo et al. (2018) and Jiménez and San Martín (2014) suggested that trust would play a middleman function between different places of origin variables and purchase intentions. Also, it has been demonstrated that the feelings of like or dislike towards a preferred product (i.e. the favourability of the product) can mediate the relationship between ethnocentrism and purchasing intention (Juharsah and Hartini, 2014). Other researchers looked into the mediation effect within the relationship variables, where brand love is argued to act as a significant mediator that influences the impact of brand identification and trust on the consumer's purchase behaviour (Albert and Merunka, 2013; Carroll and Ahuvia, 2006).

Grounded on previous research that provided us with a reasonable basis to explore the sequential multi-mediation relations in the model. We argue that, for consumers who develop high regional ethnocentrism, a strong sense of in-group protection will be activated, which will cause a fracture in the consumer relationship with brands of dual origin nature, presented in the form of distancing oneself from an untrustworthy brand that no longer 
reflects the one's inner and/or social self, and in turn, this feeling will weaken the emotional attachment and love toward the brand and eventually justify boycotting decision. Therefore, it would be interesting to address the next exploratory research question:

RQ1. Is there a possible mediating role of brand relationship variables (i.e. via brand identification, trust and love) on the path between regional ethnocentrism and the consumer's willingness to boycott?

\section{Research methodology}

\subsection{Region of origin, product category and brand selection}

We focus our attention in this study on the Spanish context, in the light of the political turbulence and conflicts in Catalonia (a Spanish region located in the northeast of Spain). Catalonia has its own language and distinctive traditions; it is considered one of the richest and most economically important regions in Spain, also a major touristic destination in Europe (Vaczi, 2016). In recent years, there have been growing calls for Catalonia independence, which created dilemmas and a long history of internal political conflicts with the Spanish Government regarding matters such as education, taxation and public investments (Cuadras-Morató and Raya, 2016). In 2017, political tensions elevated to its highest limits, when the central government took direct control over the situation after the Catalan regional election and the unilateral declaration of independence (Maza et al., 2019).

This conflict and uncertainty had a major impact on Catalan businesses. For instance, some companies (such as Caixabank and Sabadell Bank) transferred their headquarters out of Catalonia (Periodista Digital, 2017), others (e.g. Cola Cao and Bimbo) suffered sales decline because of Spanish boycott calls to Catalan products (Periodista Digital, 2017).

One of the brands that received strong attention during previous (Cuadras-Morató and Raya, 2016) and current (Regulatory Council of Cava, 2017) Catalan boycott calls and still under threat of other possible boycott is the "Cava" originated from Catalonia, which is the one chosen for this study. In fact, a great deal of mass media attention was devoted to this particular item in the past, which had been called the "Cava boycott" (Cuadras-Morató and Raya, 2016). The well-known protected designation of origin - sparkling wine - known as "Cava" (PDO Cava) is a multi-regional brand that is mainly, but not only, produced in Catalonia (Chamorro et al., 2015). It is ranked as one of the top brands with most wineries in Spain (Vinetur, 2015).

According to Vinalium (2018), the production of Cava began in the 19th century in the Catalan municipality of Sant Sadurní d'Anoia (Chamorro et al., 2015), where it became known as the "capital of Cava". Followed by a national expansion in the 20th century, where the brand established itself in the Spanish market, beyond its regional territory of Catalonia, and became one of the leading brands in the Spanish national market. Throughout the years, Cava maintained its high association with the Catalan region, even with it being a multiregional brand that has production locations across the country, in Aragon, Extremadura, La Rioja, Castile and Leon, Basque Country, Navarre and Valencia, working under the PDO of Cava (Cava Regulatory Council, 2019; Sanchez, 2019). Perhaps because Catalonia represents over $85 \%$ of the production area of Cava, that is why the brand is still being identified in the Spanish market, as a brand typical of Catalonia (Chamorro et al., 2015).

Because of the boycott calls and political tension in Catalonia, the Catalan brands of Cava suffered a sales decline for the past few years. Nevertheless, Cava managed to make some sort of sales improvement during the first half of 2017 (Regulatory Council of Cava, 2017), but unfortunately, with the recent events, domestic sales fell back again by $1.21 \%$ in the first six months of 2018 (Francas, 2018) and domestic production decreased by 12.1\% in 2018 
(Casanova, 2019). On the contrary, Cava brands originated in other regions such as Extremadura and Valencia are living sales booming (Brunat, 2018; Cabezas, 2019). This instability and sales fluctuations forced some well-known Catalan brands of Cava such as "Codorníu" to take the lead and move its headquarters from Catalonia to La Rioja, and "Freixenet" to release a statement saying that they are discussing the moving option (Brunat, 2018).

We choose to study the Spanish wine industry because this particular product category is one of the strongest agri-food products that are highly associated with the place of origin (Bruwer and Johnson, 2010), where wine features are highly influenced by the produced location (López-Rodríguez, 2018). In addition to the importance of this industry in Spain, where according to the report prepared by The International Organization of Vine and Wine (OVI) (2018) in 2018, Spain is the leader in terms of the cultivated vines surface area (LópezRodríguez, 2018) and third in terms of the world wine producers after Italy and France, which makes it relevant to widen our knowledge and understanding about consumer attitude towards this specific product category.

Finally, the Catalan brands of Cava fit the description of dual origin brands. The PDO "Cava" is recognised and protected by the Spanish National Law 6/2015 (2015) (BOE-A2015-5288) for being a multi-regional brand with "shared" PDO, which means that the geographical location of the Cava production is split between different regions in Spain, and not only limited to Catalonia (Chamorro et al., 2015) that makes it a Spanish (national) brand. Moreover, during data collection, responders were requested to answer an introductory question about familiarity with the Catalan brands of Cava, over $90 \%$ of the sample correctly identified at least one Cava brand from Catalonia, reflecting a strong association of the brand with its Catalan origin. Thus, the interviewees, who are Spanish residents of regions out of Catalonia, were indeed familiar with the regional attachment of the Cava brand (i.e. regional brand). Furthermore, during the boycott calls against Catalonia, the Cava was clearly manifested as a brand with a duality of origin, where only the Catalan brands of Cava suffered sales decline, whereas Cava originated from other regions (such Extremadura) witnessed sales booming (Cabezas, 2019). This fact suggests that despite the brand's high association with the Catalan region, Spanish consumers recognise that multi-regionality (national) of the brand and can detect (familiar) the Catalan - apart from the non-Catalan brands of the PDO Cava.

\subsection{Data collection and measures}

For this study, before any data gathering, a pre-test took place with 5 marketing scholars and 20 experienced sparkling wine consumers, to guarantee a clear and understandable survey. The consumers were contacted outside of 5 different supermarkets at one big Spanish city, and the selection process of the 277 consumers who participated in the study was through 3 filtering questions, the requirements to answer the survey was having consumed Cava brand in the last year; being Spanish and resident in Spain; and do not being originally from Catalonia. A total of 277 personal and complete questionnaires were obtained. Participants answered the questionnaire concerning their last purchase of the Catalan brands of Cava and expressed their preferences regarding a further relationship with the brand.

The demographic and socioeconomic details of the sample can be observed in Table 1. It can be concluded that the common buyers of the Catalan brands of Cava in this study are women (55.9\%), from 35 to 54 years of age (55.3\%), usually with an educational background at university degree level (29.5\%), employed and with personal income in the range of $€ 901-1,200$ per month. Most frequently respondents stated that they were married (56.1\%). This sample profile is similar to the average Spanish consumer of alcoholic beverages, who
Between love and boycott

387 


\section{Gender}

Men

Women

$388-18-2$

Age

$25-34-13.8$

$35-44$

$45-54$

$55-64$

Educational background

No studies

Elementary education

Compulsory secondary education $\quad 11.4$

High school/middle school $\quad 14.4$

Associate's degree 22.1

University degree $\quad 29.5$

$\begin{array}{ll}\text { Postgraduate } / \mathrm{PhD} & 16.6\end{array}$

Monthly income (per individual)

$\leq € 600$

$€ 601-900$

$€ 901-1,200$

$€ 1,201-1,500$

$€ 1,501-1,800$

$€ 1,801-2,400$

$€ 2,401-3,000$

\section{Employment status}

Employed

Homemaker

Entrepreneur

Retired

$\begin{array}{ll}\text { Self-employed } & 8.7\end{array}$

$\begin{array}{lc}\text { Civil servant } & 9.1\end{array}$

Student 3

$\begin{array}{lr}\text { Unemployed } & 10.6\end{array}$

$\begin{array}{llr} & \text { Marital status } & 56.1 \\ \text { Table 1. } & \text { Married } & 129\end{array}$

Divorced/separated

$\begin{array}{lr}\text { Single } & 28.0 \\ \text { Wilow/er } & \end{array}$

have consumed alcohol in some occasion, described as 35-54 years of age (41.5\%), with intermediate to superior educational level (54.1\%), this is according to the last published five years analysis - report prepared by INE (2015).

To guarantee the validity content, we used scales from prior literature, the scales used for this study were adapted from previous literature to the context of Cava purchase. To ensure readability and clarity as suggested by Brislin (1986), the translation and back-translation were completed by three English native researchers and Spanish language professors. Thus, to measure consumer ethnocentrism, the 10-item short CETSCAl from Shimp and Sharma (1987) 
was adjusted (Jiménez-Guerrero et al., 2014). The study by Carroll and Ahuvia (2006) assisted as a basis for the scale used to assess brand love. The scale by Valta (2013) was adopted to outline the brand trust scale. The scale used to measure brand identification was adapted from the scale used by Sukortprommee (2013), and finally, the scale of boycott was adapted from Abosag and Farah (2014). All variable measures used five-point Likert scales. To perform the analyses, Statistical Package for the Social Sciences (SPSS) and linear structural relations statistical programs were used.

Brand familiarity was measured as a control variable. It was operationalised by a singleitem scale (Jiménez and San Martín, 2010), by asking the responders to indicate the Catalan brands of Cava that they can remember. In total, responders could identify 22 brands of Cava originated from Catalonia. Consumers who could correctly mention at least 3 out of the 22 identified brands were considered high familiar consumers. However, consumers who identified less than three brands were considered less familiar consumers. It should be noted that most of the identified brands were mentioned once or twice by the responders, with the exception for the well-known brands of Freixenet and Codorniu (Editorial Ecoprensa, 2015), which are the most popular Cava brands among the Spanish consumers.

\section{Analyses and results}

Before starting our analyses, we used IBM SPSS statistical software package (version 24) to screen the data extracted from the questionnaires for possible outliers, out of range or missing values. As a result, we eliminated 11 invalid questionnaires whose responders did not fit the required sample characteristic for this research, as they indicated in the filtering question that they are not buyers of any Catalan brands of Cava, which may create bias issues in our analyses.

Exploratory factor analysis was then conducted to establish the scale dimensionality by using the principal component analysis varimax rotation method. The results of our factor analysis lead us to believe that each set of items measures one single construct (unidimensional), except for brand identification. As expected, we identified two relevant dimensions: personal and social identification (Carroll and Ahuvia, 2006; Del Río et al., 2001; Sukortprommee, 2013) and, therefore, treated in this research as a higher-order construct (Carroll and Ahuvia, 2006).

Following Westjohn et al. (2009) approach, we started with a first-order analysis of brand identification construct to include it later in our second-order model as a higher-order construct. We summarised the results for the first-order measurement model of brand identification in Table 2. Our results indicate a good model fit. Also, we confirmed the discriminant validity of the first-order model, as the average variance extracted (AVE) for personal and social brand identification was greater than the squared correlations of its dimensions, where the correlation between both dimensions was found to be 0.722 (Fornell and Larcker, 1981).

We then proceeded with a confirmatory factor analysis for our second-order model, following guidelines by Bagozzi and Yi (2012), to confirm the adequate fit of the measurement model. Owing to low $R^{2}$ values and correlations of the measurement errors of the items, we had to remove some items from the assessed constructs. Next, we measured the Cronbach's alpha and composite reliability coefficients, which confirmed the reliability and internal consistency of the scales by revealing values greater than 0.8 and 0.7, respectively (Bagozzi and Yi, 1988; Bagozzi and Yi, 2012). The AVE in each case provided values higher than 0.5 (Bagozzi and Yi, 1988), by which the convergent validity was likewise corroborated. Detailed results of the measurement model estimation can be observed in Table 2. Furthermore, the discriminant validity between all the constructs was as well
Between love and boycott

389 


\begin{tabular}{|c|c|c|c|c|c|c|}
\hline Latent variable & Items & Coeff. $\lambda$ & $t$ value & Cronb. $\alpha$ & $\mathrm{CR}$ & AVE \\
\hline \multicolumn{7}{|c|}{ First-order model of brand identification } \\
\hline \multirow{3}{*}{ identification } & This brand represents me & 0.881 & 25.878 & 0.947 & 0.969 & 0.912 \\
\hline & This brand reflects my personality & & - & & & \\
\hline & This brand reflects my true self & 0.979 & 40.180 & & & \\
\hline \multirow[t]{3}{*}{$\begin{array}{l}\text { Social brand } \\
\text { identification }\end{array}$} & $\begin{array}{l}\text { This brand has a positive influence on the image } \\
\text { I have of society }\end{array}$ & 0.949 & 44.514 & 0.979 & 0.984 & 0.954 \\
\hline & $\begin{array}{l}\text { This brand has a positive impact on what others } \\
\text { think of me }\end{array}$ & 0.980 & 62.628 & & & \\
\hline & This brand improves the way society sees me & 1 & - & & & \\
\hline \multicolumn{7}{|c|}{ Second-order model } \\
\hline \multirow[t]{9}{*}{ Ethnocentrism } & $\begin{array}{l}\text { Only products that are not produced in our } \\
\text { region should be purchased from other regions }\end{array}$ & 0.686 & 12.416 & 0.838 & 0.898 & 0.504 \\
\hline & A true Spanish should buy Spanish-made products & 0.556 & 9.568 & & & \\
\hline & Buying foreign products is anti-Spanish & 0.691 & 12.623 & & & \\
\hline & $\begin{array}{l}\text { There should be a very little trading or } \\
\text { purchasing of goods from other regions unless } \\
\text { out of necessity }\end{array}$ & 1 & - & & & \\
\hline & $\begin{array}{l}\text { Spanish consumers should not buy products } \\
\text { from other regions or countries, because it } \\
\text { harms the regional/national economy and } \\
\text { causes unemployment }\end{array}$ & 0.833 & 16.483 & & & \\
\hline & Curbs should be placed on all imports & 0.587 & 10.162 & & & \\
\hline & $\begin{array}{l}\text { I prefer to buy products from my area, even if } \\
\text { they cost more }\end{array}$ & 0.631 & 10.792 & & & \\
\hline & $\begin{array}{l}\text { Spanish consumers should buy from other } \\
\text { regions or foreign countries only the products } \\
\text { that we cannot produce in ours }\end{array}$ & 0.647 & 11.556 & & & \\
\hline & $\begin{array}{l}\text { Spanish consumers who purchase products } \\
\text { made in other areas are responsible for putting } \\
\text { Spanish people out of work }\end{array}$ & 0.653 & 11.695 & & & \\
\hline \multirow[t]{5}{*}{ Brand trust } & I trust this brand & 0.827 & 18.54 & 0.877 & 0.912 & 0.680 \\
\hline & This brand never disappoints me & 0.912 & 22.666 & & & \\
\hline & This brand guarantees my satisfaction & 1 & - & & & \\
\hline & $\begin{array}{l}\text { This brand gives me the confidence to solve } \\
\text { problems with their products }\end{array}$ & 0.681 & 13.337 & & & \\
\hline & $\begin{array}{l}\text { This brand strives to do everything possible to } \\
\text { satisfy me }\end{array}$ & 0.65 & 12.475 & & & \\
\hline \multirow[t]{6}{*}{ Brand love } & This brand makes me feel good & 0.703 & 15.302 & 0.915 & 0.934 & 0.712 \\
\hline & This brand makes me very happy & 0.855 & 23.395 & & & \\
\hline & I love this brand & 0.953 & 33.598 & & & \\
\hline & This brand is a pure delight, it tastes good & 1 & - & & & \\
\hline & This brand fascinates me & 0.923 & 29.364 & & & \\
\hline & I am very attached to this brand & 0.533 & 10.033 & & & \\
\hline \multirow{5}{*}{$\begin{array}{l}\text { Brand } \\
\text { identification } \\
\text { Brand boycott }\end{array}$} & Personal Brand Identification & 1 & - & N/A & 0.857 & 0.755 \\
\hline & Social Brand Identification & 0.714 & 10.292 & & & \\
\hline & I will not buy this brand in the future & 0.890 & 27.055 & 0.949 & 0.963 & 0.896 \\
\hline & I may not buy this brand in the coming months & 0.947 & 34.325 & & & \\
\hline & $\begin{array}{l}\text { I am not willing to buy this brand in my next } \\
\text { purchase of sparkling wine }\end{array}$ & 1 & - & & & \\
\hline
\end{tabular}

Table 2.

First- and secondorder measurement models estimation
Goodness of fit: $\chi^{2}=455.230(p=0.00) ; R M S E A=0.0515 ; N F I=0.937 ; C F I=0.969 ; \quad I F I=0.969$; $R F I=0.929$

Notes: N/A: not applicable; RMSEA = root mean square error of approximation; NFI = normed fit index; $\mathrm{CFI}=$ comparative fit indx; IFI = incremental fit index; relative fix index 
confirmed (Table 3), where the AVE for each construct in every case was greater than its squared correlations with other constructs (Fornell and Larcker, 1981).

After the validation of the measurement model, the estimation of the structural equation model was followed to test the proposed hypothesis. The analyses show good fit and six out of seven hypotheses are confirmed. In Table 4, the specifics of the structural model estimation can be found, revealing that ethnocentrism diminishes brand trust, brand identification positively influences brand trust and both have a positive impact on customers' brand love. Moreover, brand love has a negative effect on boycott, where this last one is likewise positively determined by consumer ethnocentrism. Nevertheless, the relation between ethnocentrism and brand identification had not been supported in our research.

Regarding the common method variance (CMV), two statistical techniques were used to assess it: Harman's single-factor test and "marker variable" technique. First, we performed the exploratory Harman's single-factor test (Podsakoff and Organ, 1986). All five variables were constrained to a single factor using unrotated factor analysis in SPSS software. The percentage variance explained by the single factor was found to be $28.564 \%$, indicating a lack of concern for the common method bias. Second, we investigated CMV statistically by applying the "marker variable" technique suggested by Lindell and Whitney's (2001), as a more advanced approach to test for potential common method bias issues. In this technique,

\begin{tabular}{lccccccrc}
\hline Latent variable & Mean & SD & Ethnocentrism & Trust & Love & Identification & Boycott & Familiarity \\
\hline Ethnocentrism & 2.251 & 0.841 & 0.710 & $-0.173^{*}$ & $-0.134^{*}$ & $0.096 \mathrm{~ns}$ & $0.350^{* * *}$ & $-0.128^{*}$ \\
Trust & 3.788 & 0.774 & $-0.167^{*}$ & 0.825 & $0.633^{* *}$ & $0.261^{* *}$ & $-0.322^{* *}$ & $0.110 \mathrm{~ns}$ \\
Love & 2.828 & 0.851 & $-0.127^{*}$ & $0.633^{* *}$ & 0.844 & $0.353^{* *}$ & $-0.284^{* *}$ & $0.218^{* *}$ \\
Identification & 1.424 & 0.823 & $0.085 \mathrm{~ns}$ & $0.261^{* *}$ & $0.353^{* *}$ & 0.869 & $-0.122^{*}$ & $0.188^{* *}$ \\
Boycott & 2.433 & 1.360 & $0.342^{* *}$ & $0.321^{* *}$ & $0.282^{* *}$ & $-0.123^{*}$ & 0.947 & $-0.209^{* *}$ \\
Familiarity & 1.314 & 0.464 & $-0.127^{*}$ & $0.111 \mathrm{~ns}$ & $0.219^{* *}$ & $0.189^{* *}$ & $-0.208^{* *}$ & 0.997
\end{tabular}

Notes: Values below diagonal represent correlations between constructs, values on the diagonal (in italic) represent; square root of AVE and values above diagonal represent the correlations between constructs adjusted for the marker variable; $* * p<0.001 ; * p<0.05$; ns $=$ not significant
Between love and boycott

391

Table 3.

Correlation matrix of latent variables and descriptive statistics

\begin{tabular}{|c|c|c|c|}
\hline Hypothesized relations & $\begin{array}{l}\text { Coefficient } \beta \\
\quad(t \text { value })\end{array}$ & $\begin{array}{l}\text { Coefficient } \beta \\
\quad(t \text { value })^{\mathrm{a}}\end{array}$ & Result \\
\hline H1: Ethnocentrism $\rightarrow$ brand identification & $0.085(1.145) \mathrm{ns}$ & $0.088(1.185) \mathrm{ns}$ & Not supported \\
\hline H2: Ethnocentrism $\rightarrow$ brand trust & $-0.178(-2.554)^{*}$ & $-0.181(-2.572) *$ & Supported \\
\hline H3: Brand identification $\rightarrow$ brand trust & $0.241(3.988)^{* *}$ & $0.244(4.009) * *$ & Supported \\
\hline H4: Brand identification $\rightarrow$ brand love & $0.205(3.922)^{* * *}$ & $0.207(3.922)^{* *}$ & Supported \\
\hline H5: Brand trust $\rightarrow$ brand love & $0.576(10.526)^{* *}$ & $0.576(10.511)^{* *}$ & Supported \\
\hline H6: Brand love $\rightarrow$ brand boycott & $-0.236(-4.037)^{* * *}$ & $-0.236(-4.058) * *$ & Supported \\
\hline H7: Ethnocentrism $\rightarrow$ brand boycott & $0.323(4.686)^{* * * *}$ & $0.342(4.873) * * *$ & Supported \\
\hline Band familiarity $\rightarrow$ brand boycott (control) & $-0.148(-2.518)$ & $-0.126(-2.226)$ & Supported \\
\hline \multicolumn{4}{|c|}{$\begin{array}{l}\text { Goodness of fit: } \chi^{2}=526.691(p=0.00) ; R M S E A=0.0513 ; N F I=0.936 ; C F I=0.973 ; I F I=0.973 ; \\
R F I=0.937 \\
\text { Goodness of fit after controlling for } C M V: \chi^{2}=554.128(p=0.00) ; R M S E A=0.0500 ; N F I=0.933 ; C F I=0.973 ; \\
I F I=0.973 ; \text { RFI }=0.934\end{array}$} \\
\hline
\end{tabular}

Notes: $* * p<0.001 ; * p<0.05 ;$ ns $=$ not significant; the value ${ }^{\mathrm{a}}$ corresponds to results after controlling for CMV
Table 4.

Structural model estimation 
SJME

24,3

392

we included a marker variable (i.e. marital status) in our data collection, as there is no theoretical reason to relate it to any of the manifest variables (Lindell and Whitney, 2001). The lowest observed correlation $(r=0.001)$ was then used as a reasonable proxy for CMV to compute the adjusted correlations using the formula recommended by Lindell and Whitney (2001, p. 116). All coefficients in the correlation analysis, which were significant before the adjustment, remain statistically significant after controlling for the marker variable (Table 3), meaning that common method bias is not critical. We then included the marker variable in the structural model, by linking it to the exogenous variable (willingness to boycott) in the model (Jaramillo et al., 2009). The results show that the model fit and hypotheses values are consistent with the original model (Table 4), where the marker variable has an effect of $<0.1$ on the data set (i.e. non-significant). Therefore, we can confidently say that common method bias is not a serious issue in this study.

Brand familiarity was included in the analyses as a control variable, to rule out any possible unobserved familiar/unfamiliar brand's impacts on our model relationships, which may cause inflation in our results. Brand familiarity refers to the consumer's ability to recognise a particular brand and its related product category (Jiménez and San Martín, 2010). It is necessary to control for the potential influences of familiarity because of its importance in country-of-origin and ethnocentrism literature (Batra et al., 2000; Jiménez and San Martín, 2010) and its strong influence on consumer decision-making process (Kim et al., 2008).

Our results demonstrate no significant differences in the direct effects of ethnocentrism and brand love on consumer willingness to participate in boycott act against dual origin brands, after controlling for brand familiarity, which gave us a better accurate representation of the model relations and ruled out any alternative explanations for our hypotheses results.

Moreover, we have analysed the indirect relationships in the model through the mediation and multi-mediation analysis with Macro PROCESS Models 4 and 6 (Hayes, 2017), mainly with ethnocentrism (Table 5). The results indicated no mediation effect between ethnocentrism and boycott through the brand relationship variables. Meanwhile, we found that brand love mediates the relationship between identification and willingness to boycott. And the relationship between identification and love was mediated by trust, as shown in Table 5 .

\section{Discussion}

The objectives of this investigation were three-fold. Firstly, this study aimed to identify the joint impact of ethnocentrism and brand love on the consumer's willingness to participate in a boycott act against dual origin brands. Secondly, we addressed the role of consumer ethnocentrism to weaken the relationship maintained between the consumer and brands of

Table 5.

Bootstrapping analysis of the mediation effects

\begin{tabular}{lcc}
\hline Pathways & & \\
\hline Ethnocentrism $\rightarrow$ identification $\rightarrow$ boycott & $\begin{array}{c}95 \% \mathrm{CI} \\
\text { Lower/Upper }\end{array}$ \\
Ethnocentrism $\rightarrow$ trust $\rightarrow$ boycott & -0.016 & $-0.058 / 0.007$ \\
Ethnocentrism $\rightarrow$ love $\rightarrow$ boycott & 0.042 & $-0.001 / 0.102$ \\
Ethnocentrism $\rightarrow$ identification $\rightarrow$ love $\rightarrow$ boycott & 0.031 & $-0.017 / 0.085$ \\
Ethnocentrism $\rightarrow$ trust $\rightarrow$ love $\rightarrow$ boycott & 0.032 & $-0.032 / 0.099$ \\
Trust $\rightarrow$ love $\rightarrow$ boycott & 0.045 & $-0.013 / 0.115$ \\
Identification $\rightarrow$ love $\rightarrow$ boycott & -0.139 & $-0.323 / 0.048$ \\
Identification $\rightarrow$ trust $\rightarrow$ love & -0.130 & $-0.227 /-0.051$ \\
& 0.145 & $0.086 / 0.202$ \\
\hline
\end{tabular}


dual origin nature through two crucial brand relationship variables (i.e. identification and trust). Thirdly, this research sought to expand the scope of investigation on consumerbrand relationship - in the agri-food context - by introducing brands with dual origin nature. We tried to capture the complexity of the brands on three different brand relationship levels (identification, trust and love) and explore the opposite impact of the brands' duality of origin (via brand love and ethnocentrism) on boycotting intention.

As indicated in the previous section, we identify a significant negative relation between ethnocentrism and the level of trust in a dual origin brand. Our result is consistent with the finding of Truong (2018), who suggested the presence of a relation between the two constructs. However, it contradicts the finding of Lee and Mazodier (2015), where consumers did not exhibit any sign of significant change in the level of trust as a result of ethnocentric tendency. In this research, we believe that the unfavourable nature of the brand (i.e. regional origin) outweighs its favourable features (i.e. national origin), generating strong negativity towards the brand, manifested itself in the form of in-group protection (i.e. consumer ethnocentrism) and consequently leading consumers to put less faith and confidence in brands coming from that origin to deliver its expected function.

Regarding the relation between the consumer-brand relationship variables, the results demonstrate the presence of positive direct relation between brand identification and trust, which has been previously supported by He et al. (2012) and So et al. (2013). Also, in parallel with Albert and Merunka (2013) findings, both variables (i.e. identification and trust) are positively related to the promotion of love feeling towards dual origin brands, which confirm their importance as antecedent variables in developing brand love. For brands with duality of origin, we find that neither the unfavourable regional trait nor the favourable national origin of the dual origin brands has a clear impact on the sequentiality of relationship among the variables, indicating that strongly identified consumers with a trustworthy brand, would probably keep on maintaining a solid relationship with these brands, regardless of the conflicting traits the brand possesses or their level of complexity.

We also find that both ethnocentrism and brand love strongly influence consumer willingness to participate in a boycott act against dual origin brands. However, they exert opposite forces that may cause confusion to the consumer, where ethnocentrism encourages the consumer to refrain from buying such brand, which aligns with previous ethnocentrism literature (Lee et al., 2017). On the contrary, brand love weakens the consumer's desire to boycott, which is consistent with the findings of Sarkar et al. (2012). Moreover, we find that the impact of ethnocentrism to stimulate the consumer to boycott is higher than brand love's impact. In detail, this result offers an insight that even though consumers can be fond of the national origin of the dual origin brands, the negative feelings generated from the unfavourable regional origin will have a more profound influence on consumer decision to buy or boycott these brands.

Meanwhile, the effect of consumer ethnocentrism on brand identification has not been supported in our research, the degree of closeness between the consumer and a brand that reflects important identity concerns will not be affected by how ethnocentric the consumer is. This result is consistent with Shu et al. (2013) finding, in which the relation was only supported in one of the three countries examined in the study.

The chosen product category might be one possible reason for this non-significant result, the effect of ethnocentrism can vary among different food products categories (FernándezFerrín et al., 2018), in which ethnocentrism may have a more noticeable impact on the consumer-brand relationship with brands of different product categories such as clothes and cars (Fernández-Ferrín and Bande-Vilela, 2015). This fact arises the necessity to investigate other products and further compare the results. Furthermore, another potential 
explanation for this unclear association can be the presence of uncounted effects of other variables that we have not acknowledged in this investigation, such as national identity, cultural symbolism, social and personal image or perceived product quality.

The outcomes of this research may be helpful to companies operating beyond their local marketplace, especially in complex and competitive marketplaces such as the Spanish market. Thus, we propose the following managerial recommendations. Firstly, derived from the insights of our findings, we advise companies that are screening for a potential foreign or regional marketplace to focus on markets with less ethnocentric consumers and address with care foreign or regional issues that can affect their brands' attractiveness. This proposition can be implemented through carrying out initial exploratory market research before entering a new foreign market, to assess the level of ethnocentrism and acquire more information about the consumer's attitude towards brands of unfavourable origins. This can deliver major advantage to companies through painting a complete picture of the market, which can assist the firms to become more fully aware of the situation, and thus facilitates the formulation of more effective and competitive marketing strategies based on local market needs.

Secondly, for perceived unfavourable regions such as the Catalan one, brands originating in Catalonia and brands that have a duality of origin, our results can be helpful to decide which "national" or "regional" origin labelling shall work out better for their brands. Companies may want their products to be seen as nationally rooted as possible. That can be accomplished through stressing in the marketing campaigns that their brand is a "Spanish" or "national" and/or supports the Spanish or national community, which might encourage ethnocentric consumers to feature the dual origin brand as more nationally originated brand, and consequently favour the brand as an in-group brand. Also, companies can engage in public relations and social community involvement strategies that may be a useful tool in helping the brand becoming more appealing to Spanish consumers and prevent consumer loss or boycotting. However, it should be noted that accentuating the national character of the dual origin brand - instead of the regional - could have an adverse impact in the brand's own region. For example, Catalans might perceive a brand that tries to hide its regional (Catalan) identity as a "traitor" to their in-group political cause (i.e. the independence of Catalonia) that could lead to brand boycott and sales reduction in the brand's own region. For that reason, companies should carefully adapt more tailored and localised marketing strategies/tactics depending on the specific (regional) market they are targeting.

As for Spanish companies located in other regions (out of Catalonia), especially those regions with strong direct competitors to the Catalan brands, in our case, other regions with Cava production, such as Extremadura or Valencia, we believe that now it is an excellent opportunity for these companies to promote awareness about their brands' unique features and characteristics, highlighting the origin of their product and draw a picture of a highly competitive brand that can act as a good alternative to a dual origin brand originated in Catalonia. Also, we recommend brands to invest in marketing research to discover other socio-psychological aspects in the Spanish markets, as these variables are shown to be relevant to the purchase behaviour of dual origin brands or Cava in particular.

\section{Conclusion}

Supported by the logic of the social identity theory and the cognitive dissonance theory, this research contributes to the literature in the following ways. The first important contribution of this research is, identifying and statistically confirming the antecedence role of consumer's regional ethnocentrism in predicting brand trust, in light of the complexity of the brand's nature. As mentioned earlier, there are a few prior studies, with diverse findings, 
exploring the interactions between these two variables (Lee and Mazodier, 2015; Truong, 2018). Our study empirically proves that highly regional ethnocentric consumer will be less willing to put faith and confidence in such brands. This result offers a relevant insight that advances empirical knowledge in the field of the place of origin.

Secondly, this research contributes to the existing literature, through introducing "dual origin" brands, with three different levels of origin traits. The complexity of the brand nature comes from the opposite or confusing characteristics that the brand possesses, being a national brand linked to a conflicting regional origin. Where most of the previous agri-food and boycott literature analysed brands using a single origin of the brand (Ahmed et al., 2018; Lee et al., 2016; Lesáková, 2016; Truong, 2018), our research pays attention to the possible and conflicting duality of origin, especially in the agri-food industry. Thirdly, another contribution of this paper is that we are the first, as far as the authors' knowledge, to analyse the joint impact of ethnocentrism and brand love on the willingness to participate in a boycott act against dual origin brands. Our results reveal that regional ethnocentrism displays a more profound impact on stimulating boycotting decision over the indirect impact through brand love. This finding could be a valuable contribution to highly diversified markets, especially in the context of dual origin brands.

To recap, we reveal some interesting contributions and new insights, which assisted in providing useful managerial implications. In brief, our results reveal that ethnocentric rejection can diminish the level of confidence in dual origin brands and encourage consumers to boycott. Moreover, brand trust and identification can definitely promote a strong feeling of love towards dual origin brands, and consequently, this love can reduce the desire to participate in boycott act against brands with a duality of origin. Furthermore, brand love can play a mediating role between identification and boycott. As well as trust that mediates the relation of identification and love.

Although this study makes several valuable contributions, the findings of this study should be considered in light of a few limitations that should be acknowledged and further investigated in future avenues of research directions. Firstly, we consider a specific product category (sparkling wine), which is exclusively viewed as a hedonic product, and therefore more lovable than other products that can be described as utilitarian products (Carroll and Ahuvia, 2006), such as milk or potatoes (Fernández-Ferrín and Bande-Vilela, 2015). For this reason, to enhance our model generalisability, it would be beneficial to broaden the range of product categories analysed, to include not only hedonic but also other products (i.e. utilitarian) that were not considered in this study. Secondly, we solely focus on one Spanish region (Catalonia), however, given the geographical diversity of the country and the intracultural differences between regions, it would be desirable to amplify the study by including other regions within Spain and other similar countries with internal conflicts between regions to establish comparability and generalisation of our findings. In the same vein, it is important to note that the majority of our data was mainly referred to a specific geographical location in Spain. Therefore, the results could be biased from this perspective and not reflect the entire situation across different regions in Spain. Future studies should consider a broader sample, including respondents from other regions, especially those with Cava production, such as Extremadura or Valencia.

Thirdly, it is necessary to point out that this research examines two constructs related to the place of origin (i.e. ethnocentrism and boycotting intention). However, it does not acknowledge the impact of consumer animosity on the proposed model; as it was not the main focus of the research, but it should be examined in future research. Fourthly, we did not measure the specific weights of the brand (regional and national) dimensions. Meanwhile, given the brand distinct origin traits, it is important to assign weights for its 
dimensions and determine the ones with the most impact on consumer perception. We consider it an interesting line of research to propose; further research should identify the dimension that carries the most weight in shaping the overall consumer perception and preference for such complex brands.

Fifthly, and finally, we recognise the presence of no mediation effect between ethnocentrism and boycott through brand relationship variables. To address this issue, further research could examine other (relationship) variables, brand loyalty as an example, that were not considered in this study and could mediate the relationship between the two variables and, consequently, clarify the mechanism of ethnocentrism effect on the boycott through consumer-brand relationship variables. Further research should be directed towards conducting an experiment, by controlling certain variables, such as the different origin traits of the brand; the level of knowledge with the brand's associated origin; the consumer's general perception regarding brands originating from a specific unfavourable region; the consumer's level of connection with a certain region, other than his/her own ingroup origin; and the level of the perceived threat of dual origin brands to the well-being of the consumer's own region of origin.

\section{References}

Abosag, I. and Farah, M.F. (2014), "The influence of religiously motivated consumer boycotts on brand image, loyalty and product judgment", European Journal of Marketing, Vol. 48 Nos 11/12, pp. 2262-2283.

Ahmed, Z.U., Hinck, W. and Felix, R. (2018), "Twenty-five years after the fall of the Berlin wall: an empirical revisit of West German consumers' attitudes toward products and brands from former East Germany", Journal of Promotion Management, Vol. 24 No. 6, pp. 895-910.

Ahuvia, A.C., Batra, R. and Bagozzi, R.P. (2009), "Love desire and identity: conditional integration theory of the love of things", in MacInnis, D.J., Park, C.W. and Priester, J.R. (Eds),The Hand-Book of Brand-Relationships, ME Sharpe, New York, NY, pp. 342-357.

Albert, N. and Merunka, D. (2013), "The role of brand love in consumer-brand relationships", Journal of Consumer Marketing, Vol. 30 No. 3, pp. 258-266.

Albert, N., Merunka, D. and Valette-Florence, P. (2008), "Loving a brand across cultures: a French/US comparison", 2008Academy of Marketing Science Cultural Perspectives in Marketing Conference, New Orleans, LA.

Bagozzi, R.P. and Yi, Y. (1988), "On the evaluation of structural equation models", Journal of the Academy of Marketing Science, Vol. 16 No. 1, pp. 74-94.

Bagozzi, R.P. and Yi, Y. (2012), "Specification, evaluation, and interpretation of structural equation models", Journal of the Academy of Marketing Science, Vol. 40 No. 1, pp. 8-34.

Balabanis, G. and Diamantopoulos, A. (2004), "Domestic country bias, country-of-origin effects, and consumer ethnocentrism: a multidimensional unfolding approach", Journal of the Academy of Marketing Science, Vol. 32 No. 1, pp. 80-95.

Batra, R., Ahuvia, A. and Bagozzi, R.P. (2012), “Brand love”, Journal of Marketing, Vol. 76 No. 2, pp. 1-16.

Batra, R., Ramaswamy, V., Alden, D.L., Steenkamp, J.B.E. and Ramachander, S. (2000), "Effects of brand local and nonlocal origin on consumer attitudes in developing countries", Journal of Consumer Psychology, Vol. 9 No. 2, pp. 83-95.

Bhandari, M. and Rodgers, S. (2018), "What does the brand say? Effects of brand feedback to negative eWOM on brand trust and purchase intentions", International Journal of Advertising, Vol. 37 No. 1, pp. 125-141.

Brislin, R.W. (1986), "The wording and translation of research instruments", Field Methods in CrossCultural Research: Cross-Cultural Research and Methodology Series, Vol. 8, pp. 137-164. 
Brunat, D. (2018), "El boicot desata la 'Guerra del cava' entre productores catalanes y el resto de España”, available at: www.elconfidencial.com/empresas/2018-01-21/guerra-cava-freixenetcodorniu-extremadura-valencia_1508167/ (accessed 10 February 2019).

Bruwer, J. and Johnson, R. (2010), "Place-based marketing and regional branding strategy perspectives in the California wine industry", Journal of Consumer Marketing, Vol. 27 No. 1, pp. 5-16.

Cabezas, R. (2019), "El cava extremeño no se resiente en España y mantiene sus ventas", available at: www.elperiodicoextremadura.com/noticias/almendralejo/cava-extremeno-noresiente-espanamantiene-sus-ventas_1171188.html/ (accessed 6 June 2020).

Between love and boycott

Carroll, B.A. and Ahuvia, A.C. (2006), "Some antecedents and outcomes of brand love", Marketing Letters, Vol. 17 No. 2, pp. 79-89.

Casanova, G. (2019), "La producción de cava cae un 12\% en el mercado español a causa del 'procés", available at: https://elpais.com/economia/2019/06/18/actualidad/1560853618_211192.html (accessed 8 July 2019).

Cava Regulatory Council (2019), "List of base wine manufacturing companies 2019", available at: www. docava.es/wp-content/uploads/2016/02/EMPRESAS-ELABORADORAS-VINO-BASE-2019.pdf (accessed 7 June 2020).

Chamorro, A., Rubio, S. and Miranda, F.J. (2015), "The region-of-origin (ROO) effect on purchasing preferences: the case of a multiregional designation of origin”, British Food Journal, Vol. 117 No. 2, pp. 820-839.

Charton-Vachet, F. and Lombart, C. (2018), "Impact of the link between individuals and their region on the customer-regional brand relationship", Journal of Retailing and Consumer Services, Vol. 43, pp. 170-187.

Cheah, I. (2010), "Rediscovering Australian brands: the roles of categorisation theory and confirmation bias on country of ownership cues", Doctoral dissertation, Curtin University.

Cheah, I., Phau, I., Kea, G. and Huang, Y.A. (2016), "Modelling effects of consumer animosity: consumers' willingness to buy foreign and hybrid products", Journal of Retailing and Consumer Services, Vol. 30 No. 5, pp. 184-192.

Cuadras-Morató, X. and Raya, J.M. (2016), "Boycott or buycott? Internal politics and consumer choices", The BE Journal of Economic Analysis and Policy, Vol. 16 No. 1, pp. 185-218.

Del Río, A.B., Vazquez, R. and Iglesias, V. (2001), "The effects of brand associations on consumer response", Journal of Consumer Marketing, Vol. 18 No. 5, pp. 410-425.

Editorial Ecoprensa, S.A. (2015), "Codorníu y freixenet:el cava catalán apuesta por el lujo y la españolidad", available at: www.eleconomista.es/evasion/gourmet/noticias/7170212/11/15/Codorniu-y-Frexenetel-cava-catalan-apuesta-por-el-lujo-y-la-espanolidad-html/ (accessed 3April 2019).

Ettenson, R. and Gabrielle Klein, J. (2005), "The fallout from French nuclear testing in the South Pacific: a longitudinal study of consumer boycotts", International Marketing Review, Vol. 22 No. 2, pp. 199-224.

Farah, M.F. and Newman, A.J. (2010), "Exploring consumer boycott intelligence using a socio-cognitive approach", Journal of Business Research, Vol. 63 No. 4, pp. 347-355.

Fehr, B. (1988), "Prototype analysis of the concepts of love and commitment", Journal of Personality and Social Psychology, Vol. 55 No. 4, p. 557.

Fernández-Ferrín, P. and Bande-Vilela, B. (2013), "Regional ethnocentrism: antecedents, consequences, and moderating effects", Food Quality and Preference, Vol. 30 No. 2, pp. 299-308.

Fernández-Ferrín, P. and Bande-Vilela, B. (2015), "Attitudes and reactions of Galician (Spanish) consumers towards the purchase of products from other regions", Global Business and Economics Review, Vol. 17 No. 2, pp. 131-150.

Fernández-Ferrín, P., Bande, B. and Galán-Ladero, M.M. (2017), "Parental influence on the levels of regional ethnocentrism of youth: an exploratory analysis", Spanish Journal of Marketing - Esic, Vol. 21 No. 1, pp. 52-62. 
Fernández-Ferrín, P., Calvo-Turrientes, A., Bande, B., Artaraz-Miñón, M. and Galán-Ladero, M.M. (2018), "The valuation and purchase of food products that combine local, regional and traditional features: the influence of consumer ethnocentrism”, Food Quality and Preference, Vol. 64 No. 3, pp. 138-147.

Festinger, L. (1957), A Theory of Cognitive Dissonance, Stanford University Press.

Fetscherin, M., Boulanger, M., Gonçalves Filho, C. and Souki, G.Q. (2014), "The effect of product category on consumer brand relationships", Journal of Product and Brand Management, Vol. 23 No. 2, pp. 78-89.

Fornell, C. and Larcker, D.F. (1981), "Evaluating structural equation models with unobservable variables and measurement error", Journal of Marketing Research, Vol. 18 No. 1, pp. 39-50.

Fournier, S. (1998), "Consumers and their brands: developing relationship theory in consumer research", Journal of Consumer Research, Vol. 24 No. 4, pp. 343-373.

Francas, R. (2018), "Las ventas de cava suben un 0, 73\% hasta el mes de junio", available at: www. lavanguardia.com/economia/20180907/451683055982/ventas-cava-mercado-espanol.html/ (accessed 10 February 2019).

García-Gallego, J.M. and Chamorro-Mera, A. (2016), "The region-of-origin effect on the preferences of financial institution's customers: analysis of the influence of ethnocentrism”, BRQ Business Research Quarterly, Vol. 19 No. 3, pp. 206-218.

García-Gallego, J.M. and Chamorro-Mera, A. (2017), "COO vs ROO: importance of the origin in customer preferences towards financial entities”, International Marketing Review, Vol. 34 No. 2, pp. 206-223.

García-Gallego, J.M. and Chamorro-Mera, A. (2018), "The region-of-origin effect in the choice of banks", International Journal of Bank Marketing, Vol. 36 No. 7, pp. 1367-1385.

García-Gallego, J.M., Chamorro-Mera, A. and García-Galán, M.M. (2015), “The region-of-origin effect in the purchase of wine: the moderating role of familiarity", Spanish Journal of Agricultural Research, Vol. 13 No. 3, p. 1.

Guo, G., Tu, H. and Cheng, B. (2018), "Interactive effect of consumer affinity and consumer ethnocentrism on product trust and willingness-to-buy: a moderated-mediation model", Journal of Consumer Marketing, Vol. 35 No. 7, pp. 688-697.

Ha, H.Y. and Perks, H. (2005), "Effects of consumer perceptions of brand experience on the web: brand familiarity, satisfaction and brand trust", Journal of Consumer Behaviour, Vol. 4 No. 6, pp. $438-452$.

Hashim, S. and Kasana, S. (2019), "Antecedents of brand hate in the fast food industry”, Spanish Journal of Marketing - ESIC, Vol. 23 No. 2, pp. 227-248.

Hayes, A.F. (2017), Introduction to Mediation, Moderation, and Conditional Process Analysis: A Regression-Based Approach, Guilford publications.

He, H., Li, Y. and Harris, L. (2012), "Social identity perspective on brand loyalty", Journal of Business Research, Vol. 65 No. 5, pp. 648-657.

INE (2015), "Encuesta Europea de Salud 2014", available at: www.ine.es/dyngs/INEbase/es/operacion. $\mathrm{htm}$ ?c=Estadistica_C\&cid=1254736176784\&menu=resultados\&idp $=1254735573175 /$ (accessed 10 February 2019).

Jacobi, L. (2018), "Ethnocentric attitudes of American and international students: assessing the impact of collaboration", Journal of Intercultural Communication Research, Vol. 47 No. 6, pp. 530-544.

Jaramillo, F., Grisaffe, D.B., Chonko, L.B. and Roberts, J.A. (2009), "Examining the impact of servant leadership on salesperson's turnover intention", Journal of Personal Selling and Sales Management, Vol. 29 No. 4, pp. 351-365.

Jiménez, N. and San Martín, S. (2008), "El etnocentrismo y la animosidad del consumidor como antecedentes de la intención de compra de productos extranjeros', estableciendo puentes en una economía global”, Escuela Superior de Gestión Comercialy Marketing, ESIC, Vol. 2, p. 24. 
Jiménez, N. and San Martín, S. (2016), “A cross-national effect of ethnocentrism on purchase intention”, International Business: Concepts, Methodologies, Tools, and Applications, IGI Global, pp. $1555-1584$.

Between love and boycott

Jiménez, N. and San Martín, S. (2010), "The role of country-of-origin, ethnocentrism and animosity in promoting consumer trust. The moderating role of familiarity", International Business Review, Vol. 19 No. 1, pp. 34-45.

Jiménez, N. and San Martín, S. (2014), "The mediation of trust in country-of-origin effects across countries", Cross-Cultural Management: An International Journal, Vol. 21 No. 2, pp. 150-171.

Jiménez-Guerrero, J.F., Gázquez-Abad, J.C. and del Carmen Linares-Agüera, E. (2014), "Using standard CETSCALE and other adapted versions of the scale for measuring consumers' ethnocentric tendencies: an analysis of dimensionality", BRQ Business Research Quarterly, Vol. 17 No. 3, pp. 174-190.

Juharsah, J. and Hartini, H. (2014), "The role of attitude as relationship mediation between products knowledge and ethnocentrism on purchasing intention of Buton special woven (study on the city of Bau-Bau)", International Journal of Business and Management Invention, Vol. 3 No. 11, pp. 26-34.

Kim, D.J., Ferrin, D.L. and Rao, H.R. (2008), "A trust-based consumer decision-making model in electronic commerce: the role of trust, perceived risk, and their antecedents", Decision Support Systems, Vol. 44 No. 2, pp. 544-564.

Kipnis, E., Kubacki, K., Broderick, A.J., Siemieniako, D. and Pisarenko, N.L. (2012), “They don't want us to become them': brand local integration and consumer ethnocentrism", Journal of Marketing Management, Vol. 28 Nos 7/8, pp. 836-864.

Klein, J.G., Ettenson, R. and Morris, M.D. (1998), "The animosity model of foreign product purchase: an empirical test in the People's Republic of China”, Journal of Marketing, Vol. 62 No. 1, pp. 89-100.

Klein, J.G., Smith, N.C. and John, A. (2004), "Why we boycott: consumer motivations for boycott participation”, Journal of Marketing, Vol. 68 No. 3, pp. 92-109.

Lam, S.K., Ahearne, M. and Schillewaert, N. (2012), "A multinational examination of the symbolic instrumental framework of consumer-brand identification", Journal of International Business Studies, Vol. 43 No. 3, pp. 306-331.

Lee, R. and Mazodier, M. (2015), "The roles of consumer ethnocentrism, animosity, and cosmopolitanism in sponsorship effects", European Journal of Marketing, Vol. 49 Nos 5/6, pp. 919-942.

Lee, R., Lee, K.T. and Li, J. (2017), "A memory theory perspective of consumer ethnocentrism and animosity”, European Journal of Marketing, Vol. 51 Nos 7/8, pp. 1266-1285.

Lee, W.J.T., Cheah, I., Phau, I., Teah, M. and Elenein, B.A. (2016), "Conceptualising consumer regiocentrism: examining consumers' willingness to buy products from their own region", Journal of Retailing and Consumer Services, Vol. 32 No. 1, pp. 78-85.

Lesáková, D. (2016), "Ethnocentric behaviour in the Slovak population: do Slovaks purchase Slovak dairy products?”, Ekonomický Časopis, Vol. 64 No. 8, pp. 795-807.

Lindell, M.K. and Whitney, D.J. (2001), "Accounting for common method variance in cross-sectional research designs", Journal of Applied Psychology, Vol. 86 No. 1, p. 114.

Lopez-Lomelí, M.Á., Llonch-Andreu, J. and Rialp-Criado, J. (2019), "Local, global and glocal consumer brand relationships", Spanish Journal of Marketing-ESIC, Vol. 23 No. 3, pp. 437-459.

López-Rodríguez, J., Dopico, D.C. and Puente, A.M.D.C. (2018), "Export performance in Spanish wineries: the role of human capital and quality management system”, European Journal of International Management, Vol. 12 No. 3, pp. 311-333.

Maher, A.A. and Mady, S. (2010), “Animosity, subjective norms, and anticipated emotions during an international crisis”, International Marketing Review, Vol. 27 No. 6, pp. 630-651. 
Maza, A., Villaverde, J. and Hierro, M. (2019), “The 2017 regional election in Catalonia: an attempt to understand the pro-independence vote", Economia Politica, Vol. 36 No. 1, pp. 1-18.

Moon, S.J., Costello, J.P. and Koo, D.M. (2017), "The impact of consumer confusion from eco-labels on negative WOM, distrust, and dissatisfaction”, International Journal of Advertising, Vol. 36 No. 2 , pp. 246-271.

Oberecker, E.M. and Diamantopoulos, A. (2011), “Consumers' emotional bonds with foreign countries: does consumer affinity affect behavioral intentions?", Journal of International Marketing, Vol. 19 No. 2, pp. 45-72.

Orth, U.R. and Krška, P. (2001), "Quality signals in wine marketing: the role of exhibition awards”, The International Food and Agribusiness Management Review, Vol. 4 No. 4, pp. 385-397.

Oskam, J. (2014), “A new state in Europe? Scenarios for Catalan self-determination”, Futures, Vol. 64, pp. 51-60.

Ouellet, J.F. (2007), "Consumer racism and its effects on domestic cross-ethnic product purchase: an empirical test in the United States, Canada, and France", Journal of Marketing, Vol. 71 No. 1, pp. 113-128.

Periodista Digital (2017), "Bimbo, Cola Cao y otras empresas catalanas proindependentistas han sufrido una caída en ventas del 40\%”, available at: www.periodistadigital.com/economia/empresas/ 2017/12/27/bimbo-cola-cao-y-otras-empresas-catalanas-proindependentistas-han-sufrido-unacaida-en-ventas-del-40.shtml/ (accessed 10 February 2019).

Podsakoff, P.M. and Organ, D.W. (1986), "Self-reports in organisational research: problems and prospects", Journal of Management, Vol. 12 No. 4, pp. 531-544.

Rather, R.A., Tehseen, S. and Parrey, S.H. (2018), "Promoting customer brand engagement and brand loyalty through customer brand identification and value congruity", Spanish Journal of Marketing-ESIC, Vol. 22 No. 3, pp. 321-339.

Regulatory Council of Cava (2017), "Global report 2017”, available at: www.docava.es/wp-content/ uploads/2018/11/globalreport2017_eng.pdf/(accessed 8July 2019).

Riefler, P. and Diamantopoulos, A. (2007), "Consumer animosity: a literature review and a reconsideration of its measurement”, International Marketing Review, Vol. 24 No. 1, pp. 87-119.

Rodrigues, C. and Rodrigues, P. (2019), "Brand love matters to millennials: the relevance of mystery, sensuality and intimacy to neo-luxury brands", Journal of Product and Brand Management, Vol. 28 No. 7, pp. 830-848.

Romero, J. and Ruiz-Equihua, D. (2020), "Be a part of it: promoting WOM, eWOM, and content creation through customer identification", Spanish Journal of Marketing - ESIC, Vol. 24 No. 1, pp. 55-71.

Samiee, S., Shimp, T.A. and Sharma, S. (2005), "Brand origin recognition accuracy: its antecedents and consumers' cognitive limitations", Journal of International Business Studies, Vol. 36 No. 4, pp. 379-397.

Sanchez, M. (2019), "Estos son nueve de los mejores cavas hechos fuera de Cataluña", available at: www.alimente.elconfidencial.com/gastronomia-y-cocina/2019-12-08/mejores-cavas-hechosfuerade-cataluna-990_2366763/ (accessed 7 June 2020).

Sarkar, A., Ponnam, A. and Murthy, B.K. (2012), "Understanding and measuring romantic brand love", Journal of Customer Behaviour, Vol. 11 No. 4, pp. 324-347.

Sharma, P. (2015), "Consumer ethnocentrism: reconceptualisation and cross-cultural validation", Journal of International Business Studies, Vol. 46 No. 3, pp. 381-389.

Sharma, S., Shimp, T.A. and Shin, J. (1994), "Consumer ethnocentrism: a test of antecedents and moderators", Journal of the Academy of Marketing Science, Vol. 23 No. 1, pp. 26-37.

Shimp, T.A. and Sharma, S. (1987), "Consumer ethnocentrism: construction and validation of the CETSCALE”, Journal of Marketing Research, Vol. 24 No. 3, pp. 280-289. 
Shu, S.T., Strombeck, S. and Hsieh, C.L. (2013), "Consumer ethnocentrism, self-image congruence and local brand preference: a cross-national examination”, Asia Pacific Management Review, Vol. 18 No. 1.

Siamagka, N.T. and Balabanis, G. (2015), "Revisiting consumer ethnocentrism: review, reconceptualisation, and empirical testing", Journal of International Marketing, Vol. 23 No. 3, pp. 66-86.

Siemieniako, D., Kubacki, K., Glińska, E. and Krot, K. (2011), "National and regional ethnocentrism: a case study of beer consumers in Poland", British Food Journal, Vol. 113 No. 3, pp. 404-418.

Şirvanll, A. (2011), "The private label tendencies of the consumers during the purchasing process", Doctoral-dissertation.

So, K.K.F., King, C., Sparks, B.A. and Wang, Y. (2013), "The influence of customer brand identification on hotel brand evaluation and loyalty development", International Journal of Hospitality Management, Vol. 34 No. 9, pp. 31-41.

Spanish National Law 6/2015 (2015), "Ley 6/2015, de 12 de Mayo, de denominaciones de origen e indicaciones geográficas protegidas de ámbito territorial supraautonómico", available at: www.boe.es/buscar/pdf/2015/BOE-A-2015-5288-consolidado.pdf (accessed 6 April 2020).

Stokburger-Sauer, N., Ratneshwar, S. and Sen, S. (2012), "Drivers of consumer-brand identification", International Journal of Research in Marketing, Vol. 29 No. 4, pp. 406-418.

Suetrong, P., Pires, G.D. and Chen, T. (2018), “Conceptualising the effect of brand love on consumers' repurchase intentions for consumer products", Global Business and Economics Review, Vol. 20 No. 2, pp. 213-230.

Sukortprommee, S. (2013), "The effect of corporate brand personality on customer-contact employee's prosocial behavior and the mediating effect of brand identification in Japanese automotive service sector", Doctoral-dissertation.

Sumner, W.G. (1906), Folkways: A Study of the Sociological Importance of Usages. Manners, Customs, Mores, and Morals, Gin and Company, Boston, MA, p. 12.

Tajfel, H. (1982), "Social psychology of intergroup relations", Annual Review of Psychology, Vol. 33 No. 1, pp. 1-39.

Teuber, R. (2010), "Geographical indications of origin as a tool of product differentiation: the case of coffee", Journal of International Food and Agribusiness Marketing, Vol. 22 Nos 3/4, pp. 277-298.

The International Organization of Vine and Wine (OVI) (2018), "OVI 2018 report on the world vitivinicultural situation", available at: www.oiv.int/en/oiv-life/oiv-2018-report-on-the-worldvitivinicultural-situation/ (accessed 10 February 2019).

Truong, N.X. (2018), "The impact of Hallyu 4.0 and social media on Korean products purchase decision of Generation C in Vietnam", KODISA 14th International Conference, Seoul, pp. 141-144.

Tuškej, U. and Podnar, K. (2018), "Exploring selected antecedents of consumer-brand identification: the nature of consumer's interactions with product brands", Baltic Journal of Management, Vol. 13 No. 4, pp. 451-470.

Vaczi, M. (2016), “Catalonia's human towers: nationalism, associational culture, and the politics of performance", American Ethnologist, Vol. 43 No. 2, pp. 353-368.

Valta, K.S. (2013), "Do relational norms matter in consumer-brand relationships?”, Journal of Business Research, Vol. 66 No. 1, pp. 98-104.

Veloutsou, C. and Delgado-Ballester, E. (2018), "New challenges in brand management", Spanish Journal of Marketing-ESIC, Vol. 22 No. 3, pp. 255-272.

Verlegh, P.W. (2007), "Home country bias in product evaluation: the complementary roles of economic and socio-psychological motives", Journal of International Business Studies, Vol. 38 No. 3, pp. 361-373. 
SJME

24,3

Vinalium (2018), "HISTORIA DEL CAVA", available at: https://vinalium.com/es/historia-del-cava/ (accessed 22 March 2020).

Vinetur (2015), "How many wineries are there in Spain?”, available at: www.vinetur.com/2016090125256/ cuantas-bodegas-hay-en-espana.html/ (accessed 10 February 2019).

Westjohn, S.A., Arnold, M.J., Magnusson, P., Zdravkovic, S. and Zhou, J.X. (2009), "Technology readiness and usage: a global-identity perspective", Journal of the Academy of Marketing Science, Vol. 37 No. 3, pp. 250-265.

\section{Corresponding author}

Dalia Abdelwahab can be contacted at: dabdelwahab@ubu.es

For instructions on how to order reprints of this article, please visit our website: www.emeraldgrouppublishing.com/licensing/reprints.htm

Or contact us for further details: permissions@emeraldinsight.com 